\title{
Quality characteristics of string cheese added with red ginseng powder
}

\author{
Jayeon Yoo, Jeongshin Choi, Kuk-Hwan Seol, Jeong-hee Yun, Jun-Sang Ham* \\ National Institute of Animal Science, RDA, Wanju 55365, Korea
}

\section{홍삼 분말을 첨가한 스트링 치즈의 품질 특성

\author{
유자연 · 최정신 · 설국환 · 윤정희 · 함준상* \\ 농촌진흥청 국립축산과학원
}

\begin{abstract}
According to health functional food law in Korea, red ginseng is classified as a health functional ingredient. In order to establish the optimal manufacturing condition of red ginseng string cheese, red ginseng powder was added to string cheese in different manufacturing processes which are raw milk before pasteurization (T1), curd before stretching (T2), and hot water for stretching curd (T3), respectively. After 2 weeks of storage period, the hardness of control cheese was lowest and decreased, as compared to 0 week, while the hardness of all string cheese with red ginseng powder was maintained (p<0.05). Total amount of ginsenoside Rb1, Rg1, and $R g 3$ was $34.41 \mathrm{mg} / \mathrm{kg}$ in $\mathrm{T1}, 55.99 \mathrm{mg} / \mathrm{kg}$ in $\mathrm{T}$, and $59.47 \mathrm{mg} / \mathrm{kg}$ in T3, respectively. All the red ginseng string cheese in this study might be labeled as functional foods which can provide legal requirement of more than $3 \mathrm{mg}$ for boosting immunity and fatigue improvement. Because the sensory score of $\mathrm{T} 2$ was highest in texture, taste, and overall preference during storage period, it is recommended to add red ginseng powder before stretching curd for making red ginseng-added string cheese.
\end{abstract}

Key words : string cheese, red ginseng

\section{서 론}

저출산 현상 지속, 대체 음료시장 확대 등 소비 여건 변화 로 인해 국민 1 인당 흰 우유 소비량은 2016년 $27.0 \mathrm{~kg}$ 에서 2019년 $26.7 \mathrm{~kg}$ 으로 정체하고 있는 한편, 치즈 소비는 동일 기간 $2.8 \mathrm{~kg}$ 에서 $3.2 \mathrm{~kg}$ 으로 증가하고 있다(Korean Dairy Committee, 2020). 그러나 국내산 치즈에 비해 상대적으로 저렴하고 다양화된 수입산 치즈의 물량 증가로 인해 국내산 자연치즈의 다양화·차별화 전략이 요구되고 있다.

'찢어먹는 치즈'로 잘 알려진 스트링 치즈(string cheese)는 신선치즈의 한 종류로, 이탈리아가 원산지인 모짜렐라 치즈 (mozzarella cheese)의 제조방법을 응용한 치즈이다. 스트링 치즈는 살균한 우유에 스타터 유산균과 렌넷(응유 효소)을
첨가하여 응고시킨 커드를 열수에 담가 반죽하여 엿가락처럼 늘려주는 것을 반복하여 만들어진다. 국내 유가공 낙농가에서 는 치즈 만들기 체험 프로그램에 이 스트링 치즈를 주로 활용 하고 있으며, 아이 간식이나 술안주 등에도 보편적으로 사용 되고 있다.

홍삼(red ginseng)은 수삼을 쪄서 익혀 말린 건강기능식품 으로, 항산화 효과(Sung 등, 2000)와 항바이러스, 항균 등 면 역 효과(Lee, 2020), 뇌혈관 반응도 및 뇌혈류 증가(Jeong 등, 2006), 모발 밀도와 굵기 증가 등 탈모 개선(Kim 등, 2009), 주름 생성 억제와 피부 개선(Kim 등, 2012; So 등, 2008) 등 의 효능이 있으며, 이는 다양한 동물실험과 임상실험으로 검 증되어왔다. 이러한 홍삼을 식품에 접목한 연구로는 홍삼 분 말을 스펀지케이크나 식빵, 설기떡에 접목하여 적정 첨가 비

*Corresponding author. E-mail : hamjs@korea.kr, Phone :+82-63-238-7366, Fax : +82-63-238-7397

Received 09 March 2021; Revised 02 April 2021; Accepted 05 April 2021.

Copyright (c) The Korean Society of Food Preservation.

This is an Open Access article distributed under the terms of the Creative Commons Attribution Non-Commercial License (http://creativecommons.org/licenses/by-nc/4.0) which permits unrestricted non-commercial use, distribution, and reproduction in any medium, provided the original work is properly cited. 
율 및 제조 방법을 제시한 연구(Seo 등, 2015; Shin 등, 2009; Song과 Shin, 2016), 우유와 두유를 2:1로 혼합하고, 홍삼 추 출물의 첨가량을 달리하여 제조한 발효유의 특성 연구 (Bae 와 Nam, 2006) 등이 있다. 또한 일반적으로 두부를 제조할 경우 압착공정으로 인해 홍삼 추출물 첨가 시 손실이 발생되 는데, 이를 개선하기 위하여 연두부 형태로 제조한 후 특성을 분석한 연구도 진행되었다(Hwang과 Lee, 2014). 치즈 분야에 서는 Park 등(2014)이 홍삼 추출액에 김치 유래 Lactobacillus acidophilus를 첨가한 발효액을 커드에 첨가하고, 유청을 걸 러 쿼크 치즈(quark cheese) 타입 신선 치즈를 제조하고 적정 첨가 농도를 $1 \%$ 로 제시하였으며, Choi 등(2015)은 홍삼 추 출물의 첨가 비율을 달리하여 제조한 아시아고 치즈의 품질 을 분석하고 적정 첨가비율을 도출한 바 있다. 또한 살균, 냉 각 처리한 원유에 홍삼 분말을 첨가하여 제조한 까망베르 치 즈의 품질 특성과 항산화능을 분석하여 기능성 치즈 개발 가 능성을 확인한 연구 사례도 있다(Lee와 Bae, 2017). 이렇듯 홍삼을 치즈에 접목한 연구가 다수 추진되었으나, 국내 소비 자가 즐겨 먹는 스트링 치즈와의 접목은 다뤄지지 않은 실정 이다. 또한 우유로 치즈를 제조할 경우 대부분의 양이 유청으 로 배출, 폐기되기 때문에 홍삼을 첨가한 치즈 내 홍삼 성분 이 어느 정도 잔류하고 있는지에 대한 효율과 경제성에 대한 고려가 필요하다. 따라서 본 연구에서는 홍삼을 첨가한 스트 링 치즈의 최적 제조기술을 확립하기 위하여 원유와 커드(고 형물), 그리고 커드의 성형 시 활용되는 열수에 각각 홍삼 분 말을 첨가하여 제조한 스트링 치즈의 품질 특성에 대해 분석 하였다.

\section{재료 및 방법}

\section{공시재료 및 치즈 제조}

스트링 치즈는 Fig. 1 의 제조공정을 적용하여 국립축산과 학원 낙농과에서 생산된 양질의 원유로 제조하였으며, 포천 인삼영농조합에서 생산된 6년근 홍삼 분말을 사용하였다. 치 즈 제조 단계별 홍삼 분말의 첨가 비율은 우유에서부터 제조된 치즈의 수율을 $10 \%$ 로 가정하여 설정하였다. 원유는 $65^{\circ} \mathrm{C}$ 에서 30 분간 살균하여 냉각시켜 주었는데, $\mathrm{T} 1$ 처리구의 경우 원유 살균 전 홍삼 분말을 원유 무게의 $0.5 \%$ 만큼 첨가하였다. 3 $4^{\circ} \mathrm{C}$ 까지 냉각한 원유에 상업용 스타터 TM 81(Danisco, France)을 접종하여 40분 유지한 후, 렌넷(Naturen Standard plus 290, Chr Hansen, New Zealand)을 첨가하고 40분간 유 지하였다. 응고된 커드는 가로, 세로 $1 \mathrm{~cm}$ 크기로 절단하여 $43^{\circ} \mathrm{C}$ 까지 올려주는 가온 과정을 거친 후, 15 분 추가 교반하 였다. 추가 교반이 완료된 이후에는 정치시켜주고, 유청의 $\mathrm{pH}$ 가 5.9에 도달 시 유청을 전량 배출하여 커드의 $\mathrm{pH}$ 가 5.2

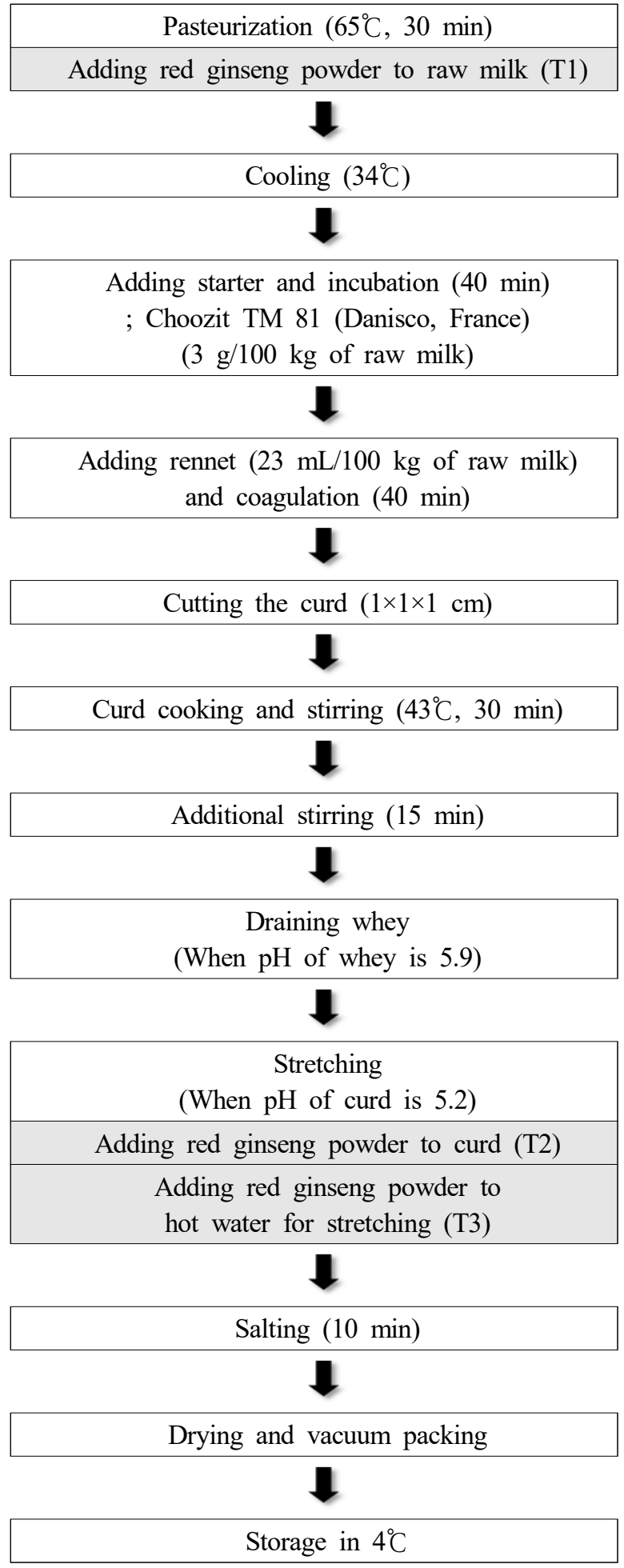

Fig. 1. Procedure of string cheese production added with red ginseng powder.

까지 떨어지면 열수에 녹여 성형을 개시하였다. 커드를 잘게 다진 후 $75^{\circ} \mathrm{C}$ 열수에 담가 반죽하여 늘림으로써 스트링 치즈 
의 모양을 만들어 주게 되는데, $\mathrm{T} 2$ 처리구의 경우, 다진 커드 에 무게 대비 $5 \%$ 의 홍삼 분말을 첨가하여 혼합한 후 성형 하 였으며, $\mathrm{T} 3$ 는 $75^{\circ} \mathrm{C}$ 열수에 마찬가지로 $5 \%$ 의 홍삼 분말을 첨 가하여 여기에 일반 커드를 담가 성형해 주었다. 홍삼 분말을 원유에 첨가한 $\mathrm{T} 1$ 의 첨가 비율은 $0.5 \%$ 로, 커드와 열수에 각 각 $5 \%$ 씩 첨가한 $\mathrm{T} 2$ 및 $\mathrm{T} 3$ 와 첨가 비율이 다른 것은 치즈 제 조 시 수율을 $10 \%$ 로 가정하였을 때, 원유 $100 \mathrm{~kg}$ 으로 제조 시 $90 \mathrm{~kg}$ 은 유청(whey)으로 배출되고, 나머지 $10 \mathrm{~kg}$ 만이 커드 가 되기 때문에 최종적으로 형성되는 커드의 양을 고려하여 동일한 수준으로 첨가해 주었다. 대조구(C)의 경우 홍삼 분말 은 첨가하지 않고, 그 외 모든 과정을 처리구와 동일하게 제조 하였다. 성형 완료한 치즈들은 처리구별로 포화소금물에 담가 10 분간 염지한 후, $4^{\circ} \mathrm{C}$ 의 냉장 온도에서 13 시간 동안 표면 건 조시켜 진공 포장하였다. 완성된 치즈는 $4^{\circ} \mathrm{C}$ 의 냉장고에 보관 하면서 저장기간 0 주, 2 주차 품질 특성 분석을 진행하였다.

\section{일반성분 및 $\mathrm{pH}$ 측정}

수분과 단백질, 지방, 염분의 분석은 Anderson 등(2007)의 방법에 준하여 Foodscan(78810, Foss, Hillerod, Denmark) 장비를 활용하여 측정하였으며, 치즈의 $\mathrm{pH}$ 는 치즈 분석용 pH meter (HI98165, Hanna, Nusfalau, Romania)를 치즈에 탐침하여 5 반복 분석하였다.

\section{조직감 측정}

한국산업표준에서 제정한 고령친화식품 물성 측정 방법 (Korean Agency for Technology and Standards, 2017)에 따라 치즈 시료는 가로, 세로, 높이 $1 \mathrm{~cm}$ 크기로 절단하여 준비하고, Instron(Model 5543, Instron, Norwood, MA, USA)을 활용하 여 경도(hardness), 탄력성(springiness), 응집성(cohesiveness) 항목을 분석하였다. 직경 $10 \mathrm{~mm}$ 의 원형 probe를 사용하였 고, $2 \mathrm{~mm} / \mathrm{s}$ 의 Test speed와 70\%의 compression으로 5 회 반 복하여 측정하였다.

\section{색도 측정}

치즈의 색도는 색차계(CR-400, Konica Minolta, Tokyo, Japan)를 활용하여 명도(lightness, L*)와 황색도(yellowness, $\mathrm{b}^{*}$ 를 5 반복 측정하였으며, 이 때 사용된 표준 백색판은 $\mathrm{Y}$ 값 이 87.3, x값이 0.32 , y값이 0.32 였다.

\section{진세노사이드 함량 분석}

치즈의 홍삼 성분을 측정하기 위하여 진세노사이드 $\mathrm{Rb} 1$, $\mathrm{Rg} 1, \mathrm{Rg} 3$ 의 함량을 분석하였다. 치즈 시료를 $1 \mathrm{~g}$ 정량 후 10 $\mathrm{mL}$ methanol에 30 분간 초음파 추출 처리하였으며, 분석에는 HPLC(Ultimate 3000, Thermo Fisher, Sunnyvale, CA, USA)
및 TSQ Endura(Thermo Fisher)를 활용하였으며 이온화 방 식에는 H-ESI(Heated electrospray ionization)를 적용하였다. 진세노사이드 $\mathrm{Rb} 1, \mathrm{Rg} 1, \mathrm{Rg} 3$ 의 표준물질은 ChemFace (Wuhan, China)에서 구입하여 사용하였고, column은 Kinetex $\mathrm{C}_{18}(2.6 \mu \mathrm{m}, 100 \mathrm{~mm} \times 21 \mathrm{~mm}$, Phenomenex, Torrance, CA, USA)을 사용하였으며, 이동상 용매로는 $5 \mathrm{mM}$ ammonium formate를 포함한 $0.1 \%$ formic acid 수용액과 $5 \mathrm{mM}$ ammonium formate와 $0.1 \%$ formic acid를 포함한 methanol을 사용하였 고 column temperature는 $35^{\circ} \mathrm{C}$, 샘플 injection volume은 10 $\mu \mathrm{L}$, flow rate는 $0.3 \mathrm{~mL} / \mathrm{min}$ 으로 실시하였다.

\section{관능적 기호도 검사}

관능 평가를 위한 치즈 시료는 가로, 세로, 높이 각 $1 \mathrm{~cm}$ 크기로 균일하게 절단하였으며, Yoo 등(2017)의 방법으로 국립축산과학원 축산물이용과의 훈련된 패널 10 명이 참여하 여 색, 향미, 조직감, 맛, 종합적 기호도에 대한 기호 점수를 9점 척도법으로 평가하였다. 관능평가는 공용기관생명윤리 위원회 심의 결과 승인(P01-202102-23-006)을 받아 시행하 였다.

\section{통계 처리}

분석 결과는 SAS Enterprise Guide 7.1(SAS Institute Inc., Cary, NC, USA)를 활용하여 ANOVA 분석하였으며 Duncan 의 다중검정(multiple range test)으로 $5 \%$ 의 유의성 수준으로 시료 간의 통계적 유의성을 분석하였다.

\section{결과 및 고찰}

\section{일반성분 및 $\mathrm{pH}$}

제조 단계별로 홍삼 분말을 첨가한 스트링 치즈의 일반성 분 및 $\mathrm{pH}$ 분석 결과는 Table 1 과 같다. 원유 단계에 홍삼 분 말을 첨가한 $\mathrm{T} 1$ 의 수분함량이 다른 처리구에 비해 유의적으 로 높게 나타났으나, 그 외 처리구는 대조구와 큰 차이가 없 었다. 이는 홍삼 분말을 첨가한 설기떡의 특성을 분석한 연구 (Shin 등, 2009)에서 홍삼 분말에 따른 수분 함량의 변화가 없게 나타난 결과와 유사하였으며, 홍삼 추출액을 첨가한 아 시아고 치즈(Choi 등, 2015)에서 수분함량이 증가한 것과는 상반되는 결과였다. 액상과 달리 분말 성상의 홍삼을 첨가할 경우 일반성분에 큰 영향을 미치지 않는 것으로 보여지며, $\mathrm{T} 1$ 의 경우 홍삼 분말이 렌넷에 의한 우유의 응고 작용에 영 향을 미쳐 수분함량이 높은 것으로 추측된다. 처리구에 비해 대조구의 단백질 함량이 유의적으로 낮고, 지방 함량과 염분 은 더 높게 나타났다. 저장기간이 경과함에 따라 $\mathrm{T} 2$ 를 제외 한 치즈의 수분함량은 증가하는 경향을 보였으며, 이는 저장 
Table 1. Proximate composition and $\mathrm{pH}$ of string cheese added with red ginseng powder

\begin{tabular}{|c|c|c|c|c|c|c|}
\hline \multicolumn{2}{|c|}{ Sample $e^{1)}$} & Moisture (\%) & Protein $(\%)$ & Fat $(\%)$ & Salinity (\%) & $\mathrm{pH}$ \\
\hline \multirow{4}{*}{0 week } & $\mathrm{C}$ & $44.43 \pm 0.39^{2 \mathrm{~b} b 3)}$ & $22.18 \pm 0.29^{b}$ & $28.86 \pm 0.28^{\mathrm{a}}$ & $1.24 \pm 0.02^{\mathrm{a}}$ & $5.12 \pm 0.04^{\mathrm{a}^{*}}$ \\
\hline & $\mathrm{T} 1$ & $45.13 \pm 0.20^{\mathrm{a}}$ & $22.74 \pm 0.18^{\left.\mathrm{a}^{*} 4\right)}$ & $27.26 \pm 0.08^{\mathrm{c}^{*}}$ & $1.09 \pm 0.01^{\mathrm{b}}$ & $4.91 \pm 0.01^{\mathrm{b}}$ \\
\hline & $\mathrm{T} 2$ & $44.26 \pm 0.05^{\mathrm{b}}$ & $22.74 \pm 0.18^{\mathrm{a}}$ & $27.42 \pm 0.07^{\mathrm{c}}$ & $1.06 \pm 0.00^{\mathrm{b}}$ & $5.03 \pm 0.00^{\mathrm{ab} *}$ \\
\hline & $\mathrm{T} 3$ & $44.58 \pm 0.17^{b}$ & $22.94 \pm 0.29^{\mathrm{a}}$ & $27.83 \pm 0.19^{b}$ & $1.11 \pm 0.07^{\mathrm{b}}$ & $5.07 \pm 0.05^{\mathrm{a}^{*}}$ \\
\hline \multirow{4}{*}{2 week } & $\mathrm{C}$ & $45.17 \pm 0.70^{\mathrm{b}}$ & $21.51 \pm 0.44^{\mathrm{b}}$ & $28.41 \pm 0.35^{\mathrm{a}}$ & $1.23 \pm 0.01^{\mathrm{ab}}$ & $4.94 \pm 0.04^{\mathrm{a}}$ \\
\hline & $\mathrm{T} 1$ & $46.11 \pm 0.22^{\mathrm{a}^{*}}$ & $22.23 \pm 0.07^{\mathrm{a}}$ & $26.38 \pm 0.16^{\mathrm{c}}$ & $1.19 \pm 0.06^{\mathrm{ab} *}$ & $4.76 \pm 0.10^{b}$ \\
\hline & $\mathrm{T} 2$ & $44.11 \pm 0.14^{\mathrm{c}}$ & $22.61 \pm 0.10^{\mathrm{a}}$ & $27.40 \pm 0.13^{b}$ & $1.25 \pm 0.05^{\mathrm{a}^{*}}$ & $4.82 \pm 0.04^{\mathrm{b}}$ \\
\hline & $\mathrm{T} 3$ & $44.84 \pm 0.23^{\mathrm{b}}$ & $22.59 \pm 0.18^{\mathrm{a}}$ & $27.66 \pm 0.13^{b}$ & $1.11 \pm 0.12^{\mathrm{b}}$ & $4.81 \pm 0.02^{\mathrm{b}}$ \\
\hline
\end{tabular}

${ }^{1)} \mathrm{C}$, string cheese (control); $\mathrm{T} 1$, string cheese made by adding red ginseng powder to raw milk; $\mathrm{T} 2$, string cheese made by adding red ginseng powder to curd; T3, string cheese made by adding red ginseng powder to hot water for stretching.

2) Data are mean $\pm \mathrm{SD}$ values $(\mathrm{n}=3)$.

${ }^{3) a-c}$ Means with different superscripts in the same column are significantly different $(p<0.05)$.

${ }^{4)^{*}}$ Means the significant differences between storage period $(\mathrm{p}<0.05)$.

기간에 따른 모짜렐라 치즈의 성분 특성을 분석한 Sulieman 등(2012)의 연구에서 저장기간 15 일차의 수분함량이 0 일차 에 비해 유의적으로 증가한 양상과 유사하였으나 본 연구에 서 $\mathrm{T} 1$ 을 제외한 처리구의 수분함량 변화에는 유의적인 차이 는 없었다. $\mathrm{pH}$ 의 경우, 홍삼분말을 첨가한 처리구에서 대조 구보다 유의적으로 낮게 나타났는데, Bae와 $\mathrm{Nam}(2006)$ 의 홍 삼 추출물 첨가 발효유 연구에서 홍삼의 첨가에 따른 $\mathrm{pH}$ 감 소는 홍삼이 citric acid, pyruvic acid와 같은 유기산을 함유 하고 있기 때문인 것으로 추측한 것과 같은 이유로 보여진다. 저장기간이 2주 경과함에 따라 치즈의 $\mathrm{pH}$ 는 모든 처리구에 서 감소하였는데, 이는 저장기간 4주까지 모짜렐라 치즈의
$\mathrm{pH}$ 가 감소하는 양상을 나타낸 Ahmed 등(2011)의 연구, 홍 삼 발효물을 첨가한 신선치즈에서 저장 15 일까지 $\mathrm{pH}$ 가 감소 한 박 등(2014)의 연구 결과와 유사하였으며, 이는 치즈 스타 터 유산균의 작용에 기인한 것으로 보여진다. 특히 박 등 (2014)은 홍삼에 함유된 당으로 인한 유산균 발효가 진행되 어 홍삼 발효물 첨가량이 많을수록 치즈의 $\mathrm{pH}$ 가 감소하 는 것으로 추측하였다.

\section{조직감}

제조 단계별로 홍삼 분말을 첨가한 스트링 치즈의 조직감 분석결과는 Table 2 와 같다. 치즈의 단단한 정도를 나타내는

Table 2. Texture of string cheese added with red ginseng powder

\begin{tabular}{|c|c|c|c|c|}
\hline \multicolumn{2}{|c|}{ Sample $^{1)}$} & Hardness $(\mathrm{N})$ & Springiness & Cohesiveness \\
\hline \multirow{4}{*}{0 week } & $\mathrm{C}$ & $5.98 \pm 0.50^{2) a 3) * 4)}$ & $0.82 \pm 0.09^{\mathrm{a}}$ & $0.52 \pm 0.06^{\mathrm{a}}$ \\
\hline & $\mathrm{T} 1$ & $4.54 \pm 0.11^{\mathrm{b}}$ & $0.98 \pm 0.07^{\mathrm{a}^{*}}$ & $0.52 \pm 0.06^{\mathrm{a}}$ \\
\hline & $\mathrm{T} 2$ & $6.20 \pm 0.90^{\mathrm{a}}$ & $0.87 \pm 0.03^{\mathrm{a}}$ & $0.52 \pm 0.07^{\mathrm{a}}$ \\
\hline & $\mathrm{T} 3$ & $5.91 \pm 0.52^{\mathrm{a}}$ & $0.80 \pm 0.16^{\mathrm{a}}$ & $0.51 \pm 0.09^{\mathrm{a}}$ \\
\hline \multirow{4}{*}{2 week } & $\mathrm{C}$ & $3.90 \pm 0.40^{\mathrm{b}}$ & $0.69 \pm 0.02^{\mathrm{b}}$ & $0.47 \pm 0.02^{\mathrm{a}}$ \\
\hline & $\mathrm{T} 1$ & $5.14 \pm 0.25^{\mathrm{a}^{*}}$ & $0.71 \pm 0.05^{\mathrm{b}}$ & $0.46 \pm 0.08^{\mathrm{a}}$ \\
\hline & $\mathrm{T} 2$ & $6.21 \pm 0.70^{\mathrm{a}}$ & $0.75 \pm 0.09^{\mathrm{ab}}$ & $0.44 \pm 0.03^{\mathrm{a}}$ \\
\hline & $\mathrm{T} 3$ & $5.22 \pm 0.71^{\mathrm{a}}$ & $0.82 \pm 0.01^{\mathrm{a}}$ & $0.41 \pm 0.03^{\mathrm{a}}$ \\
\hline
\end{tabular}

${ }^{15} \mathrm{C}$, string cheese (control); T1, string cheese made by adding red ginseng powder to raw milk; T2, string cheese made by adding red ginseng powder to curd; T3, string cheese made by adding red ginseng powder to hot water for stretching.

${ }^{2}$ Data are mean \pm SD values $(n=3)$.

${ }^{3) a, b}$ Means with different superscripts in the same column are significantly different $(\mathrm{p}<0.05)$.

${ }^{4)^{*}}$ Means the significant differences between storage period $(\mathrm{p}<0.05)$. 
경도(hardness)의 경우, 액상의 원유에 홍삼 분말을 첨가한 $\mathrm{T} 1$ 에서 유의적으로 가장 낮게 나타났으며, 커드에 첨가한 $\mathrm{T} 2$ 에서 가장 높고, 열수에 첨가한 $\mathrm{T} 3$ 는 대조구와 큰 차이를 보 이지 않은 경향을 보였다. 홍삼 분말을 첨가한 설기떡의 경도 분석 결과(Shin 등, 2009), 홍삼 분말 첨가 시 대조구에 비해 경도가 낮아졌으며, 이는 홍삼 분말로 인해 쌀가루의 상호 결 합력이 약해졌기 때문으로 보았다. T1 처리구에서도 이와 마 찬가지로 원유에 홍삼 분말을 첨가할 경우, 홍삼 분말이 렌넷 에 의한 유단백질의 응고 과정에 영향을 미쳐 수분함량이 높 고, 이로 인해 커드 형성이 약하게 된 것으로 추측된다. 고형 물인 커드에 홍삼 분말을 첨가한 $\mathrm{T} 2$ 의 경도 값이 높은 경향 을 나타낸 것은 스펀지케이크(Seo 등, 2015)나 어묵(Shim 등, 2012)의 고형물에 홍삼 분말을 첨가할 경우, 경도가 높아진 연구 결과와 유사하였다. 새싹보리 분말을 열수 성형 단계 전 에 첨가한 스트링 치즈의 특성 연구(Park 등, 2017)에서 또한 새싹보리 분말 첨가에 따라 치즈의 경도가 증가한 것과도 일 치하였다. 커드를 늘려주는 열수 성형 과정을 거치면서 스트 링 치즈는 평형의 섬유 구조를 형성하게 되는데(Gonçalves 등, 2020), 홍삼 분말을 커드에 첨가할 경우, 커드와 분말을 혼합시키기 위하여 주물러주는 과정을 거침으로써 더 단단한 특성을 가지게 된 것으로 보여진다. 반면, 커드에 홍삼 추출 액을 첨가한 아시아고 치즈의 경우(Choi 등, 2015)에서는 커 드에 홍삼 추출액을 첨가함에 따라 경도가 감소하는 양상으 로 본 연구결과와 상반되는 결과를 나타내었다. 저장기간 2 주 경과 후 대조구의 경도값은 감소하였으나, 홍삼 분말을 첨 가한 처리구의 경도는 $\mathrm{T} 1$ 의 경우 오히려 증가하였으며, $\mathrm{T} 2$ 와 $\mathrm{T} 3$ 에서는 유의적 차이를 보이지 않았고, 치즈의 탄력성과 응 집성은 대부분 감소하는 경향을 나타내었다. 저장기간이 경과 함에 따라 모짜렐라 치즈 내 응유 효소의 작용으로 $\alpha_{\mathrm{s} 1}$-casein 이 분해되고, 이로 인해 단백질 구조가 재배치, 약화되어 치 즈의 조직이 더 부드럽고, 덜 탄력적으로 변화한다고 보고된 바 있다(Tunick 등, 1997). 대조구와 달리 처리구의 경도 감 소폭이 크지 않은 것은 홍삼 분말의 영향 때문인 것으로 보이 며, 이는 스트링 치즈가 시간이 지남에 따라 물러지는 조직적 품질 저하를 완화할 수 있을 것으로 기대된다.

\section{색도}

Table 3의 색도 분석 결과, 홍삼 분말이 첨가된 스트링 치 즈의 명도(lightness, $\mathrm{L}^{*}$ )는 대조구보다 유의적으로 낮고, 황 색도(yellowness, $b^{*}$ )는 더 높게 나타나 어두운 빛을 띄었으 며, 이는 홍삼 분말 첨가 설기떡(Shin 등, 2009), 어묵(Shim 등, 2012), 까망베르 치즈(Lee와 Bae, 2017)의 색도 분석 결 과와 일치하였다. 특히 홍삼 분말을 커드에 첨가한 $\mathrm{T} 2$ 의 명 도와 황색도 값이 대조구와 가장 큰 차이를 보여 외관상으로
Table 3. Color of string cheese added with red ginseng powder

\begin{tabular}{|c|c|c|c|}
\hline \multicolumn{2}{|c|}{ Sample ${ }^{1)}$} & Lightness (L*) & Yellowness $\left(b^{*}\right)$ \\
\hline \multirow{4}{*}{0 week } & $\mathrm{C}$ & $89.28 \pm 0.31^{2) a 33 * 4)}$ & $14.70 \pm 0.83^{\mathrm{c}}$ \\
\hline & $\mathrm{T} 1$ & $83.98 \pm 0.46^{\mathrm{c}}$ & $16.83 \pm 0.31^{b}$ \\
\hline & $\mathrm{T} 2$ & $83.64 \pm 0.16^{\mathrm{c}^{*}}$ & $19.71 \pm 0.95^{\mathrm{a}}$ \\
\hline & $\mathrm{T} 3$ & $87.87 \pm 0.50^{\mathrm{b}^{*}}$ & $16.18 \pm 0.24^{\mathrm{b}}$ \\
\hline \multirow{4}{*}{2 week } & $\mathrm{C}$ & $87.39 \pm 0.23^{\mathrm{a}}$ & $15.38 \pm 0.05^{\mathrm{d}}$ \\
\hline & $\mathrm{T} 1$ & $84.26 \pm 1.10^{\mathrm{c}}$ & $18.66 \pm 0.45^{\mathrm{b}^{*}}$ \\
\hline & $\mathrm{T} 2$ & $82.25 \pm 0.08^{\mathrm{d}}$ & $20.87 \pm 0.46^{\mathrm{a}}$ \\
\hline & $\mathrm{T} 3$ & $85.46 \pm 0.13^{b}$ & $17.69 \pm 0.16^{\mathrm{c} *}$ \\
\hline
\end{tabular}

${ }^{1)} \mathrm{C}$, string cheese (control); T1, string cheese made by adding red ginseng powder to raw milk; T2, string cheese made by adding red ginseng powder to curd; T3, string cheese made by adding red ginseng powder to hot water for stretching.

${ }^{2)}$ Data are mean \pm SD values $(n=3)$.

3)a-d Means with different superscripts in the same column are significantly different $(\mathrm{p}<0.05)$.

${ }^{4)^{*}}$ Means the significant differences between storage period $(\mathrm{p}<0.05)$.

도 뚜렷한 차이를 느낄 수 있었고, 열수에 첨가한 $\mathrm{T} 3$ 의 명도 와 황색도 값은 대조구와 가장 유사하게 나타났다. 저장기간 경과에 따른 명도는 $\mathrm{T} 1$ 을 제외한 치즈에서 모두 감소하였으 며, 황색도는 모든 치즈에서 증가하는 경향을 보였고, 이는 향신료를 첨가한 모짜렐라 치즈의 특성을 28 일 동안 분석한 Akarca 등(2016)의 연구 결과와 일치하였다. 다만, Akarca 등(2016)은 치즈의 저장기간 경과에 따른 수분함량 감소가 명도 감소, 황색도 증가에 영향을 미친다고 보고하였으나, 본 연구에서는 치즈의 유의적인 수분 함량 변화가 없거나 오히 려 증가하였기에 수분 외에 색도에 영향을 미칠 수 있는 다른 요소에 대한 추가적인 검토가 필요한 것으로 보인다.

\section{진세노사이드 함량}

제조 단계별로 홍삼 분말을 첨가한 스트링 치즈의 진세노 사이드 $\mathrm{Rb} 1, \mathrm{Rg} 1$ 및 $\mathrm{Rg} 3$ 함량 분석 결과는 Table 4와 같다. 식품의약품안전처의 건강기능식품의 기준 및 규격에 따르면, 홍삼 및 홍삼 함유 기능 식품의 규격 기준이 Rg1, Rb1, Rg3 의 합으로 제시되어 있으므로 이들의 함량을 분석하였다. 치 즈 제조에 사용된 홍삼 분말의 진세노사이드 함량은 $\mathrm{Rb} 1$, $\mathrm{Rg} 1, \mathrm{Rg} 3$ 순으로 높게 나타났으며, 이를 첨가한 치즈에서도 동일 순서로 높게 나타났다. 첨가 시기에 있어서는 홍삼 분말 을 열수에 첨가한 $\mathrm{T} 3$ 의 진세노사이드 $\mathrm{Rb}, \mathrm{Rg} 1, \mathrm{Rg} 3$ 의 합이 $59.47 \mathrm{mg} / \mathrm{kg}$ 으로 가장 높게 나타났으며, 커드에 첨가한 T2 에서는 $55.99 \mathrm{mg} / \mathrm{kg}$ 으로 $\mathrm{T} 3$ 와 유의적 차이를 보이지 않았다. 원유 살균 단계에 첨가한 $\mathrm{T} 1$ 에서 $34.41 \mathrm{mg} / \mathrm{kg}$ 으로 가장 낮 게 나타났다. 치즈를 $100 \mathrm{~g}$ 단위로 환산하였을 때 $\mathrm{T} 1$ 과 $\mathrm{T} 2$, 
Table 4. Ginsenoside contents of string cheese added with red ginseng powder

(unit: $\mathrm{mg} / \mathrm{kg}$ )

\begin{tabular}{ccccc}
\hline Sample $^{1)}$ & Rb1 & $\operatorname{Rg} 1$ & $\operatorname{Rg} 3$ & Total content \\
\hline Red ginseng powder & $2,431.02 \pm 332.39^{2)}$ & $1,368.22 \pm 207.95$ & $222.30 \pm 93.13$ & $4,021.54 \pm 143.76$ \\
\hline C & $0.10 \pm 0.08^{\mathrm{c} 3)}$ & $\mathrm{ND}^{4)}$ & $\mathrm{ND}$ & $0.10 \pm 0.08^{\mathrm{c}}$ \\
T1 & $25.24 \pm 5.71^{\mathrm{b}}$ & $6.64 \pm 1.25^{\mathrm{b}}$ & $2.54 \pm 0.71^{\mathrm{b}}$ & $34.41 \pm 7.66^{\mathrm{b}}$ \\
T2 & $37.12 \pm 8.56^{\mathrm{a}}$ & $15.87 \pm 2.13^{\mathrm{a}}$ & $3.00 \pm 1.05^{\mathrm{b}}$ & $55.99 \pm 11.71^{\mathrm{a}}$ \\
T3 & $27.85 \pm 5.79^{\mathrm{ab}}$ & $18.67 \pm 2.64^{\mathrm{a}}$ & $12.94 \pm 1.98^{\mathrm{a}}$ & $59.47 \pm 10.39^{\mathrm{a}}$ \\
\hline
\end{tabular}

${ }^{1)} \mathrm{C}$, string cheese (control); T1, string cheese made by adding red ginseng powder to raw milk; T2, string cheese made by adding red ginseng powder to curd; T3, string cheese made by adding red ginseng powder to hot water for stretching.

${ }^{2)}$ Data are mean \pm SD values $(n=3)$.

3)a-c Means with different superscripts in the same column are significantly different $(\mathrm{p}<0.05)$.

${ }^{4}$ Not detected.

$\mathrm{T} 3$ 의 진세노사이드 함량은 각각 $3.4 \mathrm{mg}, 5.6 \mathrm{mg}$ 과 $5.9 \mathrm{mg}$ 으 로, 이는 식약처 건강기능식품의 기준 및 규격 내 홍삼의 면 역력 증진, 피로 개선 효과 일일 섭취량 기준 $(3-80 \mathrm{mg})$ 에 부 합하는 수준이었다. 이는 본 연구에서 적용된 치즈를 실제 판 매 시 제품에 대한 기능성 표시가 가능함을 의미한다. Park 등(2014)은 홍삼 발효물 5\%를 쿼크치즈 타입 신선치즈의 제 조 단계별로 첨가한 결과, 커드 성형 전에 첨가한 치즈에서 사포닌과 폴리페놀 함량이 $70 \%$ 이상 잔존하였다고 보고하였 다. 또한 사전 제조 및 분석에서 홍삼 추출액을 활용할 경우, 분말보다 원료 자체의 진세노사이드 함량이 낮고, 제조된 치 즈에서의 진세노사이드 잔여율도 $0.5 \%$ 내외로 분말 첨가 시 보다 더 낮게 나타남을 확인하였다(data not shown). 이상의 결과를 바탕으로 본 연구에서는 진세노사이드의 치즈 내 잔
여율을 고려하였을 때, 홍삼 추출액보다는 분말을 치즈 커드 나 열수 성형 단계에서 첨가하는 것이 원유에 첨가하는 것 보다 상대적으로 경제적인 것으로 보여진다.

\section{관능적 기호도}

홍삼 분말을 첨가한 스트링 치즈의 관능적 기호도 결과를 Table 5에 나타내었다. 색에 대한 기호 점수는 처리구에서 대 조구에 비해 유의적으로 낮게 나타났으며, 이는 홍삼 발효물 을 첨가한 쿼크치즈 타입 신선치즈(Park 등, 2014), 홍삼 분 말을 첨가한 설기떡(Shin 등, 2009)에서의 결과와 마찬가지 로 홍삼의 색상이 기호에 부정적인 영향을 미친 것으로 보인 다. 향미, 맛 등 전반적인 항목은 진세노사이드 함량이 가장 높게 나타났던 $\mathrm{T} 3$ 에서 가장 낮은 경향을 보였으나, 유의적

Table 5. Sensory scores ( 9 hedonic) of string cheese added with red ginseng powder

\begin{tabular}{|c|c|c|c|c|c|c|}
\hline \multicolumn{2}{|c|}{ Sample ${ }^{1)}$} & Color & Flavor & Texture & Taste & $\begin{array}{c}\text { Overall } \\
\text { preference }\end{array}$ \\
\hline \multirow{4}{*}{0 week } & $\mathrm{C}$ & $7.90 \pm 0.10^{2) \mathrm{a} 3)}$ & $7.07 \pm 0.29^{\mathrm{a}}$ & $7.67 \pm 0.12^{\mathrm{a}^{* 4)}}$ & $7.55 \pm 0.13^{\mathrm{a}^{*}}$ & $7.45 \pm 0.09^{\mathrm{a}^{*}}$ \\
\hline & $\mathrm{T} 1$ & $7.20 \pm 0.43^{b}$ & $7.18 \pm 0.15^{\mathrm{a}}$ & $7.58 \pm 0.10^{\mathrm{a}^{*}}$ & $7.65 \pm 0.30^{\mathrm{a}^{*}}$ & $7.60 \pm 0.20^{\mathrm{a}^{*}}$ \\
\hline & $\mathrm{T} 2$ & $7.12 \pm 0.18^{\mathrm{b}}$ & $7.23 \pm 0.18^{\mathrm{a}^{*}}$ & $7.68 \pm 0.08^{\mathrm{a}}$ & $7.60 \pm 0.10^{\mathrm{a}^{*}}$ & $7.50 \pm 0.09^{\mathrm{a}^{*}}$ \\
\hline & $\mathrm{T} 3$ & $7.35 \pm 0.18^{\mathrm{b}}$ & $6.95 \pm 0.54^{\mathrm{a}}$ & $7.58 \pm 0.38^{\mathrm{a}^{*}}$ & $7.37 \pm 0.21^{\mathrm{a}^{*}}$ & $7.35 \pm 0.30^{\mathrm{a}^{*}}$ \\
\hline \multirow{4}{*}{2 week } & $\mathrm{C}$ & $7.85 \pm 0.09^{\mathrm{a}}$ & $6.77 \pm 0.12^{\mathrm{ab}}$ & $7.00 \pm 0.18^{\mathrm{ab}}$ & $6.88 \pm 0.20^{\mathrm{a}}$ & $6.97 \pm 0.15^{\mathrm{a}}$ \\
\hline & $\mathrm{T} 1$ & $6.88 \pm 0.08^{\mathrm{c}}$ & $7.15 \pm 0.18^{\mathrm{a}}$ & $7.15 \pm 0.09^{\mathrm{a}}$ & $6.87 \pm 0.19^{\mathrm{a}}$ & $6.88 \pm 0.03^{\mathrm{a}}$ \\
\hline & $\mathrm{T} 2$ & $6.85 \pm 0.13^{\mathrm{c}}$ & $6.92 \pm 0.08^{\mathrm{ab}}$ & $7.23 \pm 0.38^{\mathrm{a}}$ & $7.08 \pm 0.08^{\mathrm{a}}$ & $7.03 \pm 0.20^{\mathrm{a}}$ \\
\hline & T3 & $7.48 \pm 0.24^{\mathrm{b}}$ & $6.57 \pm 0.33^{\mathrm{b}}$ & $6.57 \pm 0.24^{\mathrm{b}}$ & $6.72 \pm 0.25^{\mathrm{a}}$ & $6.63 \pm 0.33^{\mathrm{a}}$ \\
\hline
\end{tabular}

\footnotetext{
${ }^{1)} \mathrm{C}$, string cheese (control); T1, string cheese made by adding red ginseng powder to raw milk; T2, string cheese made by adding red ginseng powder to curd; T3, string cheese made by adding red ginseng powder to hot water for stretching.

2) Data are mean $\pm \mathrm{SD}$ values $(\mathrm{n}=3)$.

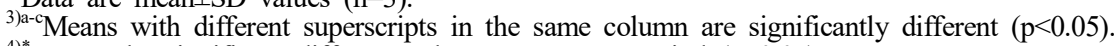

${ }^{4)^{*}}$ Means the significant differences between storage period $(\mathrm{p}<0.05)$.
} 
차이는 없었다. Bae와 $\operatorname{Nam}(2006)$ 은 홍삼 추출물을 첨가한 발효유의 향, 조직감, 맛 등 전반적 기호 점수가 추출물 함량 이 높아짐에 따라 낮게 나타났으며, 이는 홍삼 특유의 강한 향에 기인한 것으로 보고하였는데, 본 연구에서도 홍삼 성분 의 치즈 내 잔여율이 가장 높았던 T3에서의 낮은 기호 점수 는 홍삼 특유의 맛과 향에 기인한 것으로 추측된다. 저장기간 경과에 따라서는 대부분의 치즈에서 조직감, 맛, 종합적 기호 도 점수가 0 주차에 비해 2 주차에서 유의적으로 낮아졌으나, $\mathrm{T} 2$ 의 2 주차 조직감 점수는 0 주차와 유의적 차이가 없었으며, 대조구 및 다른 처리구보다 높은 경향을 나타냈다. Table 2 의 조직감 분석 결과에서 대조구와 달리 홍삼 분말 첨가 처리구 의 저장기간 경과에 따른 경도 변화는 증가하거나(T1) 큰 차 이가 없는 것으로(T2, T3) 확인하였는데, 특히 홍삼 분말을 커드에 첨가하여 성형할 경우 냉장 저장시간이 흐를수록 스 트링 치즈가 물러지는 조직적, 관능적 결함을 완화할 수 있을 것으로 기대된다. 결과적으로 저장기간에 걸친 전반적인 기 호 점수와 진세노사이드의 잔여율을 고려하였을 때, 홍삼 분 말을 커드에 첨가하여 스트링 치즈를 제조하는 것이 가장 적 합할 것으로 보인다.

\section{요 약}

국내산 자연치즈의 제품 다양화를 위하여 홍삼을 첨가한 스트링 치즈의 최적 제조기술을 확립하고자 원유(T1)와 커드 (T2), 그리고 열수(T3)에 각각 홍삼 분말을 첨가하여 스트링 치즈를 제조하고, 품질 특성을 분석하였다. 홍삼 분말 첨가 유무 및 제조공정에 따른 일반성분에는 $\mathrm{T} 1$ 의 수분 함량을 제 외하고는 큰 차이를 보이지 않았으며, 홍삼 분말이 첨가된 치 즈의 $\mathrm{pH}$ 는 대조구에 비해 유의적으로 낮게 나타났다. 치즈의 단단한 정도를 나타내는 경도는 원유에 홍삼 분말을 첨가한 $\mathrm{T} 1$ 에서 가장 낮아 무른 특성을 나타내었다. 치즈의 냉장 저 장 2 주 경과 시 대조구의 경도 값은 감소하였으나, 홍삼 분말 첨가 처리구 중 $\mathrm{T} 1$ 의 경도는 오히려 증가하였으며 $\mathrm{T} 2$ 와 $\mathrm{T} 3$ 는 0 주차와 유의적 차이가 없었다. 이는 홍삼 분말이 스트링 치즈가 시간이 지남에 따라 물러지는 조직적 품질 저하를 더 디게 할 수 있을 것으로 기대되었다. 진세노사이드 $\mathrm{Rb} 1, \mathrm{Rg} 1$, $\mathrm{Rg} 3$ 의 합은 홍삼 분말을 열수에 첨가한 T3에서 $59.47 \mathrm{mg} / \mathrm{kg}$ 으로 가장 높았으며, $55.99 \mathrm{mg} / \mathrm{kg}$ 으로 나타난 $\mathrm{T} 2$ 와 유의적 차이를 보이지 않았다. 관능적 기호도 분석 결과에서는 저장 기간 경과에 따라 대부분의 치즈에서 조직감, 맛, 종합적 기 호도 점수가 0 주차에 비해 2 주차에서 감소하였으나, $\mathrm{T} 2$ 의 2 주차 조직감 점수는 0 주차와 유의적 차이가 없었으며, 대조구 및 다른 처리구보다 높은 경향을 나타냈다. 이상의 결과를 바 탕으로 진세노사이드의 잔여율과 저장기간에 걸친 전반적인
기호 점수를 고려하였을 때, 홍삼 분말을 커드에 첨가하여 스 트링 치즈를 제조하는 것이 가장 효율적일 것으로 여겨진다.

\section{감사의 글}

본 연구는 농촌진흥청 연구사업(세부과제명: 지역 특산물 선발 및 이를 이용한 자연치즈 제조기술 개발, PJ01354403) 에 의해 이루어진 것임.

\section{Conflict of interests}

The authors declare no potential conflict of interest.

\section{ORCID}

Jayeon Yoo https://orcid.org/0000-0003-3593-5191

Jun-Sang Ham https://orcid.org/0000-0003-4966-6631

\section{References}

Ahmed NS, Abd El-Gawad MAM, EL-Abd MM, Abd-Rabou NS. Properties of buffalo mozzarella cheese as affected by type of coagulante. Acta Sci Pol Technol Aliment, 10, 339-357 (2011)

Akarca G, Caglar A, Tomar O. The effects spicing on quality of mozzarella cheese. Mljekarstvo, 66, 112-121 (2016)

Anderson S. Determination of fat, moisture, and protein in meat and meat products by using the FOSS FoodScan near-infrared spectrophotometer with FOSS artificial neural network calibration model and associated database: Collaborative study. J AOAC Int, 90, 1073-1083 (2007)

Bae HC, Nam MS. Properties of the mixed fermentation milk added with red ginseng extracts. Korean J Food Sci Ani Resour, 26, 127-135 (2006)

Choi KH, Min JY, Ganesan P, Bae IH, Kwak HS. Physicochemical and sensory properties of red ginseng extracts or red ginseng hydrolyzates-added asiago cheese during ripening. Asian Australas J Anim Sci, 28, 120-126 (2015)

Goncalves MC, Cardarelli HR. Effect of the stretching temperature on the texture and thermophysical properties of mozzarella cheese. J Food Process Preserv, 44, e14703 (2020) 
Hwang JH, Lee KH. Changes of antioxidant activities of soft tofu manufactured with red ginseng extract during storage. Korean J Food Nutr, 27, 478-483 (2014)

Jeong DW, Moon SK, Hong JW, Shin WJ, Park YM, Jung JH, Kim CH, Min IK, Park SU, Jung WS, Park JM, Go $\mathrm{CN}$, Cho KH, Kim YS, Bae HS. Effects of Korean ginseng, Korean red ginseng and fermented Korean red ginseng on cerebral blood flow, cerebrovascular reactivity, systemic blood pressure and pulse rate in humans. J Korean Oriental Med, 27, 38-50 (2006)

Kim JH, Yi SM, Choi JE, Son SW. Study of the efficacy of Korean red ginseng in the treatment of androgenic alopecia. J Ginseng Res, 33, 223-228 (2009)

Kim MJ, Kang SM. The effect of red ginseng diet on blood and facial skin improvement of married women. J Kor Soc Cosm, 18, 159-168 (2012)

Korean Agency for Technology and Standards. Standard of silver food. Korean Standard, Seoul, Korea, p 4-5 (2017)

Korean Dairy Committee. Dairy Statistics. Http://www.dairy. or.kr/kor/sub05/menu_03.html (accessed March 2021)

Lee JS, Bae IH. Quality characteristics, changes in physiochemical properties and functional properties of camembert cheese containing red ginseng powder. Korean J Food Sci Anim Resour, 38, 64-77 (2018)

Park JH, Moon HJ, Oh JH, Lee JH, Jung HK, Choi KM, Cha JD, Lim JY, Han SB, Lee TB, Lee MJ, Choi HR. Changes in the functional components of Lactobacillus acidophilus-fermented red ginseng extract and its application to fresh cheese production. Korean J Dairy Sci Technol, 32, 47-53 (2014)

Seo EO, Ko SH, Jeong HC. Research quality characteristics of sponge cake added with red ginseng powder. Korean J Culin Res, 21, 130-140 (2015)

Shim DW, Jiang J, Kim JH, Kim WW, Kang WS, Choi WS,
Hur SJ, Kim DY, Kim KC, Lee KH. Effects of size adjusted with red ginseng powders on quality of fish pastes. J Korean Soc Food Sci Nutr, 41, 1448-1453 (2012)

Shin SM, Jung JS, Han MR, Kim AJ, Kim YH. Quality characteristics of Sulgidduk containing added red ginseng powder. Korean J Food Cookery Sci, 25, 586-592 (2009)

So SH, Lee SK, Hwang EI, Koo BS, Han GH, Lee MJ, Chung JH, Kim NM. Mechanisms of Korean red ginseng and herb extracts (KTNG0345) for anti-wrinkle activity. J Ginseng Res, 32, 39-47 (2008)

Song SH, Shin GM. Quality characteristics of white pan bread with led ginseng powder. J Korean Soc Food Cult, 31, 220-225 (2016)

Sulieman AME, Ali RAM, Razig KAA. Production and effect of storage in the chemical composition of mozzarella cheese. Int J Food Sci Nutr eng, 2, 21-26 (2012)

Sung KS, Chun C, Kwon YH, Kim KH, Chang CC. Effects of red ginseng component on the antioxidative enzymes activities and lipid peroxidation in the liver of mice. $\mathrm{J}$ Ginseng Res, 24, 29-34 (2000)

Tunick MH, Cooke PH, Malin EL, Smith PW, Holsinger VH. Reorganization of casein submicelles in mozzarella cheese during storage. Int Dairy J, 7, 149-155 (1997)

Yi YD. Immune functional properties of Korean (red) ginseng as a traditional food. Food Industry and Nutrition, 25, 1-10 (2020)

Yoo JY, Park WS, Han GS, Song MY, Jeong SG, Ham JS. Quality characteristics of low-fat mozzarella cheese prepared at different cooking temperatures. J Milk Sci Biotechnol, 35, 47-54 (2017) 